University of Nebraska - Lincoln

DigitalCommons@University of Nebraska - Lincoln

USDA National Wildlife Research Center - Staff Publications
U.S. Department of Agriculture: Animal and Plant Health Inspection Service

$6-2010$

\title{
LACTATING NORTH AMERICAN BEAVERS (CASTOR CANADENSIS) SHARING DENS IN THE SOUTHWESTERN UNITED STATES
}

\author{
Justin W. Fischer \\ USDA/APHIS/WS National Wildlife Research Center, Justin.w.fischer@aphis.usda.gov \\ Roger E. Joos \\ United States Department of Agriculture \\ Melissa A. Neubaum \\ United States Department of Agriculture \\ Jimmy D. Taylor II \\ USDA/APHIS/WS National Wildlife Research Center, jimmy.d.taylor@usda.gov \\ David L. Bergman \\ United States Department of Agriculture
}

See next page for additional authors

Follow this and additional works at: https://digitalcommons.unl.edu/icwdm_usdanwrc

Fischer, Justin W.; Joos, Roger E.; Neubaum, Melissa A.; Taylor, Jimmy D. II; Bergman, David L.; Nolte, Dale L.; and Piaggio, Antoinette J., "LACTATING NORTH AMERICAN BEAVERS (CASTOR CANADENSIS) SHARING DENS IN THE SOUTHWESTERN UNITED STATES" (2010). USDA National Wildlife Research Center - Staff Publications. 1266.

https://digitalcommons.unl.edu/icwdm_usdanwrc/1266

This Article is brought to you for free and open access by the U.S. Department of Agriculture: Animal and Plant Health Inspection Service at DigitalCommons@University of Nebraska - Lincoln. It has been accepted for inclusion in USDA National Wildlife Research Center - Staff Publications by an authorized administrator of DigitalCommons@University of Nebraska - Lincoln. 


\section{Authors}

Justin W. Fischer, Roger E. Joos, Melissa A. Neubaum, Jimmy D. Taylor II, David L. Bergman, Dale L. Nolte, and Antoinette J. Piaggio 


\title{
LACTATING NORTH AMERICAN BEAVERS (CASTOR CANADENSIS) SHARING DENS IN THE SOUTHWESTERN UNITED STATES
}

\author{
Justin W. Fischer,* Roger E. Joos, Melissa A. Neubaum, Jimmy D. Taylor, David L. Bergman, \\ Dale L. Nolte, and Antoinette J. Piaggio
}

United States Department of Agriculture, Animal and Plant Health Inspection Service, Wildife Services, National Wildlife Research Center, 4101 LaPorte Avenue, Fort Collins, CO 80521 (JWF, MAN, AJP)

United States Department of Agriculture, Animal and Plant Health Inspection Service, Wildlife Services, 8836 North 23rd Avenue, Suite 2, Phoenix, AZ 85021 (REJ, DLB)

United States Department of Agriculture, Animal and Plant Health Inspection Service, Wildlife Services, National Wildlife Research Center, 9730-B Lathrop Industrial Drive SW, Olympia, WA 98512 (JDT, DLN)

Present Address of REJ: United States Department of Agriculture, Forest Service, Kaibab National Forest, 742 South Clover Road, Williams, AZ 86046

Present Address of DLN: United States Department of Agriculture, Animal and Plant Health Inspection Service, Wildlife Services, National Wildlife Research Center, 4101 LaPorte Avenue, Fort Collins, CO 80521

* Correspondent: justin.w.fischer@aphis.usda.gov

\begin{abstract}
During a radio-tracking study of North American beavers (Castor canadensis) in Arizona, we discovered three adult, lactating beavers using the same bank den at the same time. Two adult females $5.2 \mathrm{~km}$ downstream also were using the same den at the same time. For the first case, we documented use of communal dens by lactating adults on seven occasions during 68 days. For the second case, we documented communal use of a den on three occasions during 45 days. To test the hypothesis that these communal females were closely related, we used eight autosomal DNA microsatellites. Two females in the first den were first-order relatives. However, the other communal females were unrelated to the females with which they shared the den. We conclude that communal denning, where multiple females raise one or more litters in the same den, may have occurred in our study area and communal-denning partners are, in some cases, close kin.
\end{abstract}

RESUMEN-Durante un estudio de radiotelemetría del castor (Castor canadensis) en Arizona, descubrimos tres hembras adultas en lactancia usando simultáneamente la misma madriguera. Dos hembras adultas localizadas 5.2 kilómetros río abajo también utilizaban la misma madriguera al mismo tiempo. Para el primer caso, documentamos el uso comunal de madrigueras por adultas en lactancia siete veces durante 68 días. En el segundo caso, documentamos el uso por las hembras adultas de la madriguera comunal en tres ocasiones durante 45 días. Para probar la hipótesis que estas hembras comunales estuvieron estrechamente relacionadas, utilizamos ocho microsatélites de ADN autosómicos. Dos hembras en la primera madriguera tenían parentesco de primer orden. Sin embargo, las otras hembras comunales no tenían relación de parentesco entre las que compartían la madriguera. Llegamos a la conclusión que madrigueras comunales, donde varias hembras crían una o más camadas en la misma madriguera, puede haber ocurrido en nuestra área de estudio, y los co-habitantes de madrigueras son, en algunos casos, parientes cercanos.

The typical colony or family unit of the North American beaver (Castor canadensis) consists of an adult breeding pair, young of the current year, yearlings born the previous year, and occasionally, one or more nonbreeding subadults (Bradt, 1938; Aleksiuk, 1968; Svendsen, 1980; Bishir et al., 1983; Hodgdon and Lancia, 1983; Busher, 1987). Reports exist of colonies 
containing $>2$ adult females (Hay, 1958; Payne, 1982) and some studies have documented multiple lactating or pregnant females within a colony or territorial area (Bergerud and Miller, 1977; Busher et al., 1983; Wheatley, 1993; Crawford et al., 2008). Wheatley (1993) reported two pregnant North American beavers within a colony in southern Manitoba, but it was not clear whether both animals were residents of the same lodge. Conditions of the ice and distance from neighboring lodges provided anecdotal evidence that both females inhabited the same lodge. Recently, Crawford et al. (2008) examined genetic relationships within and among colonies to determine if they are a socially monogamous species. Interestingly, colonies did contain unrelated individuals and $>50 \%$ of litters had been sired by multiple males. However, no published literature has documented multiple lactating or pregnant adults residing in the same lodge or den for an extended period of time. Previous studies have used trapping to provide a snapshot in time regarding composition of colonies, but not actual use of lodge or den. Here we report two cases demonstrating multiple reproductively active females using the same den over an extended period of time.

We investigated the degree of relatedness among females sharing dens using microsatellite DNA markers. Based on similar work by Crawford et al. (2008), we predicted that communal denning occurs in populations and those females sharing dens are closely related. Therefore, we used DNA genotypes to test the hypothesis that pairwise kinship analysis between co-denning females would infer first-order relationships, with the null hypothesis that they were unrelated.

Our research was conducted on the Salt River in the southwestern portion of Phoenix, Maricopa County, Arizona, downstream of the 91st Avenue Wastewater Treatment Plant. The Salt River lies below 1,100-1,200 $\mathrm{m}$ elevations in the lower Colorado River Valley subdivision of the Sonoran desertscrub biome (Turner and Brown, 1994). Streamside vegetation traditionally was considered to be cottonwoods (Populus fremontii), willows (Salix gooddingii), and velvet mesquites (Prosopis veluntina). Currently, much of the woody vegetation has been replaced by saltcedars (Tamarix chinensis). Average annual precipitation varied from $193 \mathrm{~mm}$ near the wastewater treatment plant to $180 \mathrm{~mm}$ near the western end of our study area (Turner and Brown, 1994), with the wettest month being March (mean = $27.2 \mathrm{~mm}$ ) and the driest being June (mean = 2.3 mm; Western Regional Climate Center, http:/ / www.wrcc.dri.edu/cgi-bin/cliMAIN.pl?az6486). Temperatures ranged from an average high of $19^{\circ} \mathrm{C}$ in January to an average high of $42^{\circ} \mathrm{C}$ in July. The wastewater treatment plant released a perennial flow of ca. $5 \mathrm{~m}^{3} / \mathrm{s}$ into the Salt River and was managed by the Sub-Regional Operating Group under agreement with the cities of Phoenix, Mesa, Tempe, Scottsdale, and Glendale, Arizona. The riverbed upstream and beyond $11.4 \mathrm{~km}$ downstream from the wastewater treatment plant is dry, except during flood events. Irrigation canals flow in and out of this segment of the Salt River.

We captured, immobilized, radio-tagged, and released North American beavers downstream of the wastewater treatment plant during 20042006 (Arjo et al., 2008). Females were determined to be lactating and pregnant by presence of enlarged teats and abdominal palpation, respectively. We attached tail-mounted radiotransmitters to 43 adults weighing $>10 \mathrm{~kg}$ (12 males, 31 females; Rothmeyer et al., 2002; Baker, 2005; DeStefano et al., 2006). At this time, samples of tissue were collected from the tail for DNA analysis. We also collected hair as a secondary source of DNA. We collected tissue and hair from 54 North American beavers that were trapped (this includes the 43 that were radio-tagged) on the Salt River for DNA analysis. Radio-tracking occurred on average once per week during 0700-1130 h. Bank dens (hereafter referred to as dens) were located by homing on radio-tagged individuals. All dens located by this technique were checked every tracking occasion to determine use.

We extracted DNA from tissue with DNeasy Tissue Kits (QIAGEN, Inc., Valencia, California) and from hair using a QIAamp DNA Micro Kit (QIAGEN, Inc., Valencia, California) following protocol of the manufacturer for both types of samples. We amplified eight microsatellite markers according to protocols established by PelzSerrano et al. (2009). One of the individuals from the study site was used for development of these markers and all individuals trapped for this study were used for characterization of each marker (Pelz-Serrano et al., 2009). Amplifications were achieved using a Mastercycler EP thermocycler (Eppendorf, Hamburg, Germany) 
and genotypes were visualized using an Applied Biosystems 3130 Genetic Analyzer (Applied Biosystems, Inc., Foster City, California) following protocols of the manufacturer. Alleles were scored by employing ABI GeneMapper Software, version 4.0, and scored data was exported from GeneMapper and converted for downstream analyses using GMConvert (Faircloth, 2006). Relevant population-genetic parameters were estimated in ARLEQUIN (Excoffier et al., 2005). We also used the program Kinship 1.2 (Goodnight and Queller, 1999) to estimate relationships of pedigree between pairs of individuals in a population. This program also was used to estimate relatedness (R) between individuals. We used this program to test hypotheses of first-order relationships (parentoffspring or full siblings $=0.5$ shared pedigree on both maternal and paternal side between pairs of individuals) versus the null hypothesis of unrelated between individuals using a maximumlikelihood framework. Significance of first-order relationships was determined as at least $P<0.05$ after 9,000 simulations.

Density of colonies varied spatially and temporally, but averaged 0.7 colonies $/ \mathrm{km}$ of stream. We discovered nine dens in our study area that received at least some use by radio-tagged individuals. Two of these dens were occupied by multiple adult females for extended periods of time, suggesting that communal denning may be occurring in our study area. In the first den, we observed three lactating adults from one area using the same den at the same time. Beavers five, six, and seven were captured, determined to be lactating, and radio-marked on 1, 8, and 8 July 2004, respectively, ca. $5.6 \mathrm{~km}$ downstream of the wastewater treatment plant. All three were using a communal den $\left(33^{\circ} 22^{\prime} 50^{\prime \prime} \mathrm{N}, 112^{\circ} 18^{\prime} 37^{\prime \prime} \mathrm{W}\right)$ during a 68-day period. On six tracking occasions, two of the three were located in the same den at the same time. On one tracking occasion, all three were in the same den at the same time. Dates between tracking events, when at least two of the three were located together, were variable, but averaged 8.3 days $(S E=4.4$, range $=1$ 29 days). Beaver five lost its radio-tag shortly after tagging, but was in the communal den with either beavers six or seven on four of five tracking occasions. Beavers six and seven were in the communal den with each other or beaver five on 6 of 21 tracking occasions during the 68-day period. Communal denning of beavers six and seven ceased at the end of the 68-day period. Two adult males were trapped in this colony during the 68-day period. The hypothesis of first-order relationships was significant $(P<0.001)$ between beavers five and six, but not between five and seven or six and seven.

For the second den, we observed two adult females using a communal den during a 45-day period. Beavers 31 and 32 were captured and radio-marked (8 February and 8 June 2006, respectively) ca. $10.8 \mathrm{~km}$ downstream of the wastewater treatment plant. Beaver 31 was pregnant and beaver 32 was lactating when captured. The time lag between capture of beaver 31 (8 February 2006) and the observed communal denning (12 June, 26 June, and 27 July 2006) make it unclear as to whether or not both individuals were lactating, pregnant, or raising young in the same den at the same time. On three of three tracking occasions during the 45-day period, radio-tracking revealed these two individuals using the same den $\left(33^{\circ} 23^{\prime} 03^{\prime \prime} \mathrm{N}\right.$, $\left.112^{\circ} 21^{\prime} 45^{\prime \prime} \mathrm{W}\right)$ at the same time. Dates between tracking events were variable, but averaged 22.5 days $(S E=8.5$, range $=14-31$ days $)$. Shortly after the third radio-tracking occasion in which both were using the same den, beaver 32 was never detected again. Males were never trapped in this colony. The hypothesis of first-order relationships was rejected for beavers 31 and 32. However, there was a significant first-order relationship detected between beavers five and $32(P<0.001)$ and six and $32(P<0.05)$.

Eight loci (Pelz-Serrano et al., 2009) were amplified in each individual with 2-4 alleles/ locus and observed heterozygosity of $0.27-0.65$ (mean $=0.50)$. Each locus was in HardyWeinberg Equilibrium. Average relatedness calculated among samples was $R=0.17$.

Communal care, or more specifically, communal nesting is common in many populations of rodents and birds (Getz et al., 1992; Manning et al., 1995; McRae, 1996; for a review see Hayes, 2000). Hayes (2000) defined communal nesting as multiple females raising young and sharing parental responsibilities in the same nest. A byproduct of communal nesting, especially in rodents, is communal nursing (sharing of milk with offspring that are not their own; Hoogland et al., 1989; Manning et al., 1995; for a review see Roulin, 2002). Our trapping and radio-telemetry data indicated that some North American beavers were lactating or pregnant when sharing 
dens. These results suggest that multiple reproductive females gave birth in communal dens. Without direct behavioral observations of these multiple litters in the same den, it is unclear as to whether adults shared parental responsibilities or communal nursing occurred.

For North American beavers, the conventional family unit is comprised of a single adult breeding pair, young of the current year, and yearlings born the previous year. The social organization in our study area has appeared to add multiple reproductive females to the extended family unit. These results concur with what Crawford et al. (2008) have recently reported in that colonies may contain $>1$ pregnant female. As predicted, we determined that reproductively active females that are firstorder relatives will share a den. However, we also determined that non-relative, adult, reproductively active females will share a den. Genetic analysis of communal nesting moorhens (Gallinula chloropus) revealed that, in many cases, parents were related (McRae et al., 1996). Den sharing by San Joaquin kit foxes (Vulpes macrotis mutica) occurred primarily by members of the same social group (Ralls et al., 2001). One possible explanation of relative and non-relative, adult, reproductively active females sharing a den in this severely human-impacted environment is the habitat-saturation hypothesis. This suggests that when food and space become limited, some species will forgo dispersal and stay at the natal site, leading to individual cooperation and communal nesting (Emlen, 1982; Getz et al., 1992; Wolff, 1994; for a review see Solomon and Getz, 1997). Busher et al. (1983) stated that colonies containing more than one adult male or female may be the result of high densities. Our estimate of population density of 0.7 colonies $/ \mathrm{km}$ of stream is similar to estimates in New York (0.24-1.14 colonies/km of stream; Müller-Schwarze and Schulte, 1999), New Brunswick (0.34-1.2 colonies/km of stream; Nordstrom, 1972), and Colorado (0.35-0.6 colonies/km of stream; Breck et al., 2001). High-density populations in central and southern Illinois repeatedly exhibited delayed natal dispersal (Crawford et al., 2008). We believe that observed communal denning of adult, reproductively active females in our study area is due, to some degree, to the limited amount of available habitat (i.e., suitable sites for foraging and denning). The riverbed upstream and $>11.4 \mathrm{~km}$ downstream from the wastewater treatment plant was essentially dry. Group living among rodents has been linked to sharing burrows, if construction is costly and sites are limited (Ebensperger, 2001). The paucity of available dens and proximate high-quality food in the area could be delaying dispersal of subadults and adults, and in some instances eliminating dispersal. These ecological constraints might explain the communal denning of adult females in southwestern Phoenix, Arizona.

We thank the Sub-Regional Operations Group representing the cities of Glendale, Mesa, Phoenix, Scottsdale, and Tempe, Arizona, for providing funding and the Tres Rios Project for logistical support. Field assistance from D. Briseňo, K. Hoss, and T. Veenendaal was greatly appreciated. We appreciate helpful comments from S. Breck and D. Walter on an early draft of the manuscript and thank K. Pedersen for Spanish translation. T. Ladine and two anonymous reviewers also provided constructive comments that improved the manuscript.

\section{Literature Cited}

Aleksiuk, M. 1968. Scent-mound communication, territoriality, and population regulation in beaver (Castor canadensis Kuhl). Canadian Journal of Zoology 49:759-762.

Arjo, W. M., R. E. Joos, C. O. Kochanny, J. L. Harper, D. L. Nolte, and D. L. Bergman. 2008. Assessment of transmitter models to monitor beaver Castor canadensis and C. fiber populations. Wildlife Biology 14: 309-317.

BAKER, B. W. 2005. Efficacy of tail-mounted transmitters for beaver. Wildlife Society Bulletin 25:218-222.

Bergerud, A. T., and D. R. Miller. 1977. Population dynamics of Newfoundland beaver. Canadian Journal of Zoology 55:1480-1492.

Bisher, J., R. A. Lancia, and H. E. Hodgdon. 1983. Beaver family organization: its implications for colony size. Pages 105-113 in Investigations on beavers. Volume 4 (G. Pilleri, editor). Brain Anatomy Institute, Berne, Switzerland.

Bradt, G. W. 1938. A study of beaver colonies in Michigan. Journal of Mammalogy 19:139-162.

Breck, S. W., K. R. Wilson, and D. C. Andersen. 2001. The demographic response of bank-dwelling beavers to flow regulation: a comparison on the Green and Yampa rivers. Canadian Journal of Zoology 79: 1957-1964.

Busher, P. E. 1987. Population parameters and family composition of beaver in California. Journal of Mammalogy 68:860-864.

Busher, P. E., R. J. Warner, and S. H. Jenkins. 1983. Population density, colony composition, and local 
movements in two Sierra Nevadan beaver populations. Journal of Mammalogy 64:314-318.

Crawford, J. C., Z. Liu, T. A. Nelson, C. K. Nielsen, And C. K. Bloomquist. 2008. Microsatellite analysis of mating and kinship in beavers (Castor canadensis). Journal of Mammalogy 89:575-581.

DeStefano, S., K. K. G. Koenen, C. M. Henner, and J. Strules. 2006. Transition to independence by subadult beavers (Castor canadensis) in an unexploited, exponentially growing population. Journal of Zoology (London) 269:434-441.

Ebensperger, L. A. 2001. A review of the evolutionary causes of rodent group-living. Acta Theriologica 46: 115-144.

EmLen, S. T. 1982. The evolution of helping. I. An ecological constraints model. American Naturalist 119:29-39.

Excoffier, L., G. Laval, and S. Schneider. 2005. Arlequin version 3.0: an integrated software package for population genetics data analysis. Evolutionary Bioinformatics Online 1:47-50.

FAIRcloth, B. C. 2006. GMCONVERT: file conversion for GENEMAPPER output files. Molecular Ecology Notes 6:968-970.

Getz, L. L., D. F. Gutermuth, and S. M. Benson. 1992. Pattern of nest occupancy of the prairie vole, Microtus ochrogaster, in different habitats. American Midland Naturalist 128:197-202.

Goodnight, K. F., And D. C. Queller. 1999. Computer software for performing likelihood test of pedigree relationship using genetic markers. Molecular Ecology 8:1231-1234.

HAY, K. G. 1958. Beaver census methods in the Rocky Mountain region. Journal of Wildlife Management 22:395-402.

Hayes, L. D. 2000. To nest communally or not to nest communally: a review of rodent communal nesting and nursing. Animal Behaviour 59:677-688.

Hodgdon, H. E., ANd R. A. Lancia. 1983. Behavior of the North American beaver, Castor canadensis. Acta Zoologica Fennica 103:99-103.

Hoogland, J. L., R. H. Tamarin, and C. K. Levy. 1989. Communal nursing in prairie dogs. Behavioral Ecology and Sociobiology 24:91-95.

Manning, C. J., D. A. Dewsbury, E. K. Wakeland, and W. K. Pоттs. 1995. Communal nesting and nursing in house mice, Mus musculus domesticus. Animal Behaviour 50:741-751.

McRae, S. B. 1996. Family values: costs and benefits of communal nesting of the moorhen. Animal Behaviour 52:225-245.

Müller-Schwarze, D., AND B. A. Schulte. 1999. Behavioral and ecological characteristics of a "climax" population of beaver (Castor canadensis). Pages
161-177 in Beaver protection, management, and utilization in Europe and North America (P. E. Busher and R. M. Dzieciolowski, editors). Kluwer Academic-Plenum Publishers, New York.

Nordstrom, W. R. 1972. Comparison of trapped and un-trapped beaver populations in New Brunswick. M.S. thesis, University of New Brunswick, Fredericton.

Payne, N. F. 1982. Colony size, age, and sex structure of Newfoundland beaver. Journal of Wildlife Management 46:655-661.

Pelz-Serrano, K., A. Munguia-Vega, A. J. Piaggio, M. Neubaum, P. Munclinger, A. Partl, C. van Riper, III, AND M. Culver. 2009. Development of nine new microsatellite loci for the American beaver, Castor canadensis (Rodentia: Castoridae), and cross-species amplification in the European beaver, Castor fiber. Molecular Ecology Resources 9:551-554.

Ralls, K., K. L. Pilgrim, P. J. White, E. E. Paxinos, M. K. SChwartz, AND R. C. Fleischer. 2001. Kinship, social relationships, and den sharing in kit foxes. Journal of Mammalogy 82:858-866.

Rothmeyer, S. W., M. C. McKinstry, and S. H. Anderson. 2002. Tail attachment of modified ear-tag radio transmitters on beavers. Wildlife Society Bulletin 30: 425-429.

Roulin, A. 2002. Why do lactating females nurse alien offspring? A review of hypothesis and empirical evidence. Animal Behaviour 63:201-208.

Solomon, N. G., AND L. L. GETZ. 1997. Examination of alternative hypotheses for cooperative breeding in rodents. Pages 199-230 in Cooperative breeding in mammals (N. G. Solomon and J. A. French, editors). Cambridge University Press, Cambridge, United Kingdom.

Svendsen, G. E. 1980. Population parameters and colony composition of beaver (Castor canadensis) in Southeast Ohio. American Midland Naturalist 104:47-56.

Turner, R. M., AND D. E. Brown. 1994. Sonoran desertscrub. Pages 181-221 in Biotic communities: southwestern United States and northwestern Mexico (D. E. Brown, editor). University of Utah Press, Salt Lake City.

Wheatley, M. 1993. Report of two pregnant beavers, Castor canadensis, at one beaver lodge. Canadian Field-Naturalist 107:103.

WoLfF, J. O. 1994. Reproductive success of solitarily and communally nesting white-footed mice and deer mice. Behavioral Ecology 5:206-209.

Submitted 6 November 2008. Accepted 1 June 2009. Associate Editor was Troy A. Ladine. 